Int. J. Dev. Biol. 54: 779-786 (2010)

doi: $10.1387 /$ ijdb.092939rp

\title{
Molecular and cellular machinery of gonadal differentiation in mammals
}

\author{
RAFAL P. PIPREK* \\ Department of Comparative Anatomy, Institute of Zoology, Jagiellonian University, Kraków, Poland
}

\begin{abstract}
The direction of gonadal development is established through the predominance of one of two sex-determining pathways in bipotential gonads. When Sry is expressed, the male pathway prevails and a series of prominent changes in morphology and function of the gonad lead to testis differentiation. In the absence of Sry, the female pathway gains control of gonadal development, resulting in a lack of significant changes in the gonad, and as a consequence ovarian development becomes dormant. Several important molecular and cellular processes have been identified as operating during the development of the testis, including testis cord and vasculature formation, as well as testis-specific cell migration. Nevertheless, gene expression analysis has indicated that more genes participate in ovarian than testis development. Ovarian development is actively controlled at the molecular level and seems driven by inhibition of testis-specific processes. Current knowledge concerning genes participating in gonadal differentiation is limited, but it is apparent that this process seems more complicated than previously thought.
\end{abstract}

KEY WORDS: gonadal differentiation, Sertoli cell, proliferation, cell migration, meiosis

\section{Introduction}

At the first stage of gonadogenesis the anlage of the gonad is undifferentiated; afterwards complicated molecular interactions take place and determine gonadal sex. Sex-determining genes switch on or switch off the expression of genes that induce changes in the structure and function of gonads, contributing to gonadal differentiation. The differentiation of gonads is a complicated series of processes that evoke the development of the undifferentiated gonad into a testis or an ovary (Fig. 1). The fulfilment of the gonadal differentiation program depends on which sex-determining pathway prevails. Early studies on developing gonads showed that gonadogenesis is evolutionary conserved among vertebrates. This suggested that genetic control of gonad differentiation is more conserved than sex determination which is evolutionarily more malleable. After a switch of the expression of Sry, encoding a decisive factor for the male fate, such factors as SOX9 and FGF9 reach high concentrations in gonadal somatic cells. These cells differentiate into Sertoli cells (Fig. 2,3). These molecular interactions enable male-determining factors to protect the $X Y$ gonad against up-regulation of the ovarian pathway since SOX9 and FGF9 inhibit the female pathway (Kim et al., 2006). During the critical period of sex determination in mice, 266 genes are up-regulated and 50 genes are down- regulated in $X Y$ gonads at $11.5 d p c$ (Beverdam and Koopman, 2006). However, over the next two days of mouse development (between 11.5 and $13.5 \mathrm{dpc}$ ) 1086 genes are over-expressed in $X Y$ gonads (Nef et al., 2005). These genes drive significant structural and functional changes in the developing testis. During the sex determination period in the $X Y$ gonad, genes of the female sex determination pathway such as Rspo1 and Wnt4 are downregulated (Chassot etal., 2008). In XX gonads Rspo1, Wnt4, Dax1 and then Fox/2 are up-regulated and are responsible for establishing ovarian development.

\section{Testis versus ovary differentiation}

Anlagen of the gonads form as genital ridges comprised of thickened coelomic epithelium and are invaded by primordial

\footnotetext{
Abbreviations used in this paper: Arx, aristaless related homeobox X-linked; ATRX, $\alpha$-thalassemia, mental retardation, X-linked; Dax 1, dosage-sensitive sex reversal-adrenal hypoplasia congenita critical region on the $\mathrm{X}$ chromosome gene 1; DHH, desert hedgehog; Fgf, fibroblast growth factor; Fgfr, fibroblast growth factor receptor; Figlo, factor in germline alfa; Fst, follistatin; Rspo1, R-spondin 1; Sf1, steroidogenic factor 1; Sox9, Sry-like HMG box protein 9; Sry, sex determining region on the Y; Stra8, stimulated by retinoic acid gene 8 ; Wnt4, wingless-type MMTV integration site 4 .
}

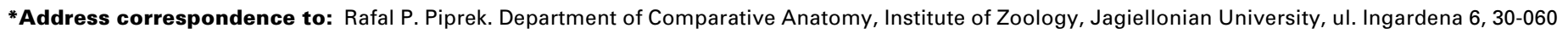
Kraków, Poland. e-mail: rafalpiprek@wp.pl
} 
germ cells. Somatic cells surrounding the anlage start to proliferate and migrate into the gonad. In mammals, the basal lamina underlying the anlage epithelium ruptures, enabling cells derived from the coelomic epithelium to fill the gonad and then surround the germ cells, which leads to the formation of sex cords. The cells in vertebrate gonads form two elements - the cortex and the medulla. The disposition of germ cells in the sex cord mass displays a sex-specific pattern. During gonad differentiation into ovary, germ cells remain in the peripheral region, thus the cortex prevails over the medulla and the sex cords vanish. In a differentiating testis, however, germ cells migrate with the developing sex cords into the gonad and thus the medulla in the testis is better developed than the cortex, the rudiment of which transforms into the tunica albuginea. This implies that the molecular control of the disposition of germ cells is one of the essential aspects of gonadal differentiation and probably results from modifications of basal lamina, extracellular matrix proteins and cell membrane components that influence cell-cell interactions. There are two hypotheses (symmetrical and asymmetrical) concerning the intercellular aspects of determination of gonadal differentiation. The symmetrical concept of Witschi (1956) suggests that the location of germ cells within the gonad determines either an oogonial or spermatogonial pathway and that somatic cells of the gonadal cortex induce oogenesis in the ovary, while cells of the medulla lead germ cell differentiation into spermatogonial cells. According to the currently preferred asymmetrical concept, oogonial cells induce the development of the cortex while somatic cells of the medulla bring about spermatogenesis in the testis (Adams and McLaren, 2002). This is in accordance with the participation of germ cells in ovarian development but not in testis development.

The proliferation of coelomic epithelial cells resulting in the prominent extension of the male gonad is the earliest symptom of testis differentiation and is essential for male-sex determination. The inhibition of cell division alters testis cords, the formation of

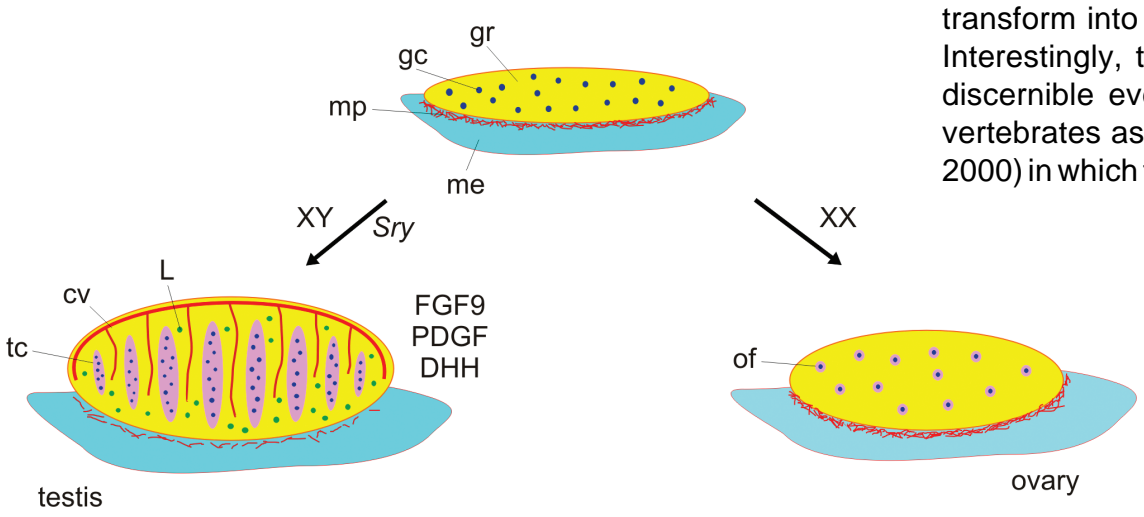

Fig. 1. Differentiation of gonads. A genital ridge (gr) is composed of somatic cells and is then invaded by primordial germ cells (gc) which are initially dispersed at $9.5 \mathrm{dpc}$ in mice. There is a large vascular plexus ( $\mathrm{mp}$ ) in the mesonephros (me) near the boundary with the gonad. The male pathway is established when Sry, Sox9 and Fgf9 are up-regulated. Then factors such as FGF9, PDGF and DHH drive structural and functional changes in the differentiating testis. At $12.5 \mathrm{dpc}$ the testis cords (tc) are formed, the primordial vascular plexus is dissolved and cells derived from this structure migrate towards the gonadal epithelium to create a large coelomic vessel (cv). The branches of this vessel are crucial for proper testis cord formation. Leydig cells (L) occur between testis cords. When factors such as RSPO1 and WNT4 prevail in the sex determination period, the gonad begins to differentiate into an ovary. Ovarian follicles (of) containing germ cells are formed, the mesonephric plexus persists and the coelomic vessel does not appear. which is the next critical event for the maintenance of Sertoli cells during testis differentiation (Schmahl and Capel, 2003). It was migration of mesonephric cells into the gonad is also critical for the establishment of testis structure (Buehr et al., 1993; Merchantarios et al., 1993; Martineau et al., 1997; Tilmann and Capel, coincides with testis-specific vascular development. Distur-

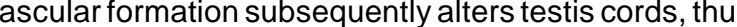
er the coelomic vessel and its branches (Brennan et al., 2002; Brennan and Capel, 2004; Combes et al., . Germ cells are prevented from entering meiosis in the (e) Meiotic cells ectopically placed in a differentiating testis affect proper mesonephric cell migration and testis ord formation and thus the testis pathway (Yao et al., 2003).

The onset of steroidogenesis is another process characteristic not to developing testis. The differentiation of Leydig cells seems orchestrating secondary male features in the rest of the body since fetal Leydig cells product androgens and insulin-like 3 . Cells of the large coelomic vessel express arterial markers such as EphrinB2, thus the vessel probably does not discharge a great amount of testosterone out of the testis as suggested previously, but rather may provide oxygen for the growing testis (Brennan et al., 2002). Further studies are needed to verify the prevalence and conservation of such sex-specific processes as somatic cell proliferation, mesonephric cell migration and coelomic vessel nation among vertebrates.

In the ovary, cell proliferation, mesonephric cell migration, testis cord and coelomic vessel formation, as well as steroidogenesis, are inhibited. Primitive sex cords in the ovary vanish and transform into nests (cysts), in which germ cells enter meiosis. differences between $X X$ and $X Y$ gonads are the rat and Monodelphis (reviewed by Mittwoch, the $X X$ gonad. This results from the accelerated growth of the $X Y$ embryo, including its gonads. On the other hand, differences at the cellular or molecular level are unknown before the sex determination period in bipotential gonads of mice (Swain and Lovell-Badge, 1999).

\section{Testis}

\section{Proliferation is the first symptom of testicu- lar differentiation}

Proliferation in the $X Y$ gonad commences at $11.2 d p c$ and onward and is visible by $12 d p c$ (Schmahl etal., 2000; Schmahl and Capel, 2003). As described above, proliferation expands the population of Sry-positive cells and thus contributes to male-sex determination. After the sexdetermining period, the testis is almost twice the size of the ovary owing to the proliferation of somatic cells (Fig. 1). FGF9, via surface receptor 
FGFR2, promotes the earliest phase of proliferation in coelomic epithelial Sf1-positive cells which transform into pre-Sertoli cells and also into other cell lineages between 11.0 and $11.5 \mathrm{dpc}$ (Karl and Capel, 1998; Schmahl et al., 2000). After Sf1 expression is terminated in the coelomic epithelium, the precursors of Sertoli cells cease to divide (at $11.5 \mathrm{dpc}$ ) but cells of coelomic epithelium continue proliferation (Fig. 3). However, this phase of testisspecific proliferation is mediated by PDGF rather than FGF9, since the loss of Pdgfro disrupts only this latter phase of proliferation and does not affect the early proliferation of $S f 1$-positve cells (Brennan et al., 2003). Cells dividing during the PDGF-mediated phase contribute only to interstitial cell formation, not to Sertoli cells. Null-mutation in Fgfr2results in a decrease in the proliferation of somatic cells in $X Y$ gonads and thus also in impairment of Sertoli cell differentiation (Kim et al., 2007). Fgfr2 displays a sexually dimorphic expression pattern (Schmahl et al., 2004). FGFR2 is initially found in the cell membrane of coelomic epithelial cells and afterwards (at $11.5 d p c$ ) is localized in the nuclei of cells scattered in the interior of the $X Y$ gonad but not in the $X X$ gonad. FGF9 is crucial but not sufficient for the induction of the nuclear localization of FGFR2 (Schmahl et al., 2004). Cells with FGFR2 localized in nuclei differentiate into Sertoli cells but do not divide rapidly. Membrane FGFR2 seems to mediate proliferation at the surface of the $X Y$ gonad, however, this receptor in nuclei can induce Sertoli cell differentiation (Brennan and Capel, 2004). FGFR2 performs distinct tasks in testis-specific proliferation and Sertoli cell differentiation (Kim et al., 2007). Moreover, the sexspecific binding of FGF9 in extracellular matrix has been shown to be enhanced in $X Y$ differentiating gonads (Schmahl et al., 2004). The assembly of glycoprotein components of the extracellular matrix, especially heparin sulfate proteoglycans (HSPGs) that act as low-affinity receptors for FGFs, can be a repository of FGF9 and may be responsible for the maintenance of a high concentration of this growth factor, ensuring testis development.

\section{Formation of testis structure}

The formation of distinct sex cords is another testis-specific event during gonadogenesis which begins when pre-Sertoli cells assemble and surround germ cells (Fig. 1,2,3). This process takes place between 11.5 and $12.5 d p c$ in mice. During this period Sertoli cells resume division within the nascent cords (Schmahl and Capel, 2003). The formation of testis cords is essential for the maintenance of the male pathway in the developing male gonad. The creation of Sertoli cell aggregations is due to changes in the expression of extracellular matrix and membrane proteins. At this time the synthesis of cytokeratins begins in Sertoli cells, while desmin is down-regulated and becomes synthesized in peritubular myoid cells that surround the testis cords (Virtanen et al., 1986; Frojdman etal., 1992). An interaction between the peritubular and Sertoli cells is required for basal lamina formation and thus for maintaining the integrity of the testis cords (Fig. 3). Disruption in peritubular myoid cell differentiation resulting from e.g. nullmutation in Dhh, encoding the desert hedgehog protein, causes impairment of testis cord formation (Yao and Capel, 2002). Peritubular myoid cells have been thought to be derived from the mesonephros (Buehr et al., 1993; Merchant-Larios et al., 1993; Martineau et al., 1997), which may explain why the absence of mesonephric cell migration impairs testis cord formation. However, the cells immigrating into the gonad are apparently endothelial cells. Additionally, EYFP driven by the promoter of $\alpha S m a$ (i.e., peritubular myoid cell marker) has not been detected in cells migrating from the mesonephros which indicates that peritubular myoid cells are not derived from the mesonephros but are rather induced within the gonad and differentiate from interstitial cells derived from the coelomic epithelium (Cool et al., 2008). Deletion of Gata4 under Sf1 promoter control results in impairment of both and testis differentiation after $14.5 d p c$, however, early stage of gonadogenesis and sex determination stay unaffected (Tevosian et al., 2009). In the males, absence of GATA4 causes development of testis cords with multiple layers of Sertoli cells. It can be hypothesized that GATA4 is essential for establishment of Sertoli cell position and thus for proper testis cord formation.

Proteases and their inhibitors, such as testatin, vanin-1, protease nexin-1 and matricellular protein SPARC, may play key roles in gonadal differentiation due to their contribution to numerous tissue remodelling processes. Testatin, the small secreted inhibitor of cysteine proteases, is specifically expressed in differentiating Sertoli cells in mice and may significantly influence testis development. However, loss-of-function mutation in the gene encoding testatin does not affect sex determination nor testis differentiation (Töhönen et al., 2005). It is possible that other proteases or protease inhibitors resume its function.

The expression of vanin-1 (Vanin-1) and protease nexin-1 ( $P n$ $1)$ is up-regulated during sex determination in $X Y$ gonads
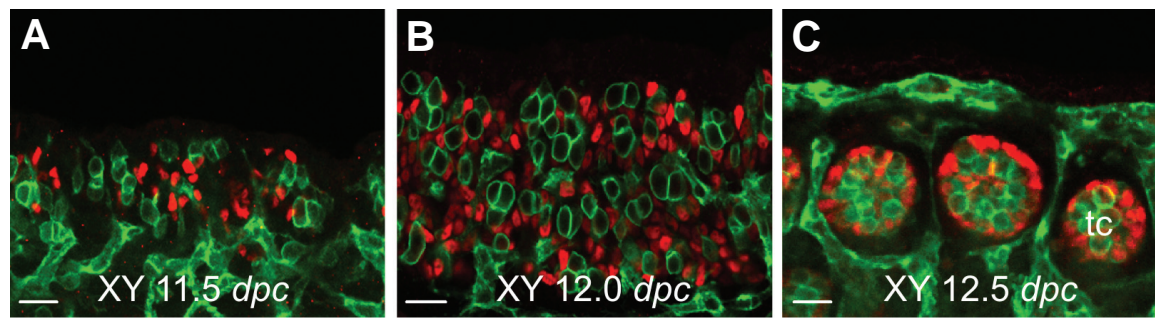

(Grimmond et al., 2000). Sf1 and Sox9, components of the male pathway, bind to the Vanin-1 promoter and enhance its transcription (Wilson et al., 2005). Vanin-1 encodes a glycosylphosphatidylinositol-linked membraneassociated pantetheinase that catalyzes the hydrolysis of pantetheine into pantothenic acid (vitamin B5) and into cysteamine, an anti-oxi-
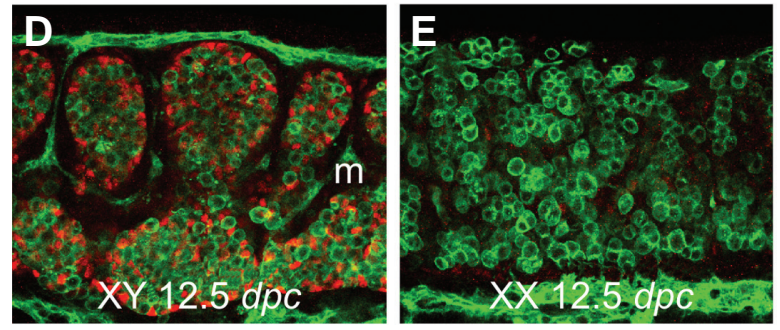

Fig. 2. Sox9 expression and the structure of developing gonad. (A,B) Sox9expressing cells (red) proliferate in XY gonad at $11.5 \mathrm{dpc}$ and onward. At $12.0 \mathrm{dpc}$ these cells, called pre-Sertoli cells, are numerous and start to surround germ cells. (C) Testis cords (tc) are discernible at $12.5 \mathrm{dpc}$ in XY gonads. Differentiating Sertoli cells tightly enclose germ cells. (D) Testis cords enlarge and mesenchymal cells as well as migrating endothelial cells $(\mathrm{m})$ are located among testis cords. (E) Sox9-expressing as well as clear sex cords are absent of differentiating ovaries. PECAM (green) marks germ cells and vascular endothelial cells. Scale bar, $25 \mu \mathrm{m}$ (reproduced from Kim et al., 2006). 
dant (Pitari et al., 2000). Thus, vanin-1 can protect male germ cells against oxidative stress, and moreover, can regulate the cell-adhesion process, which is essential for proper migration and testis cord formation. Protease nexin-1 may be responsible for the maintenance of the integrity of the basal lamina during testis cord formation (Grimmond et al., 2000).

SPARC, one of the matricellular glycoproteins important for tissue differentiation, is male-specifically expressed during testiculogenesis (Wilson etal., 2006). Surprisingly, this acidic and rich in cysteine secreted protein is localized intracellularly in Sertoli cells, germ cells and in Leydig cells. SPARC binds to growth factors, such as PDGFs and FGFs, and thus blocks their action and inhibits cell division and differentiation. Moreover, SPARC binds ECM components and disrupts cell adhesion processes (Yan and Sage, 1999; Brekken and Sage, 2001). This indicates that SPARC can drastically impair testis differentiation because it is able to alter processes such as testis cord and coelomic vessel formation through a decrease in the capacity of FGF9 and PDGF in inducing cell proliferation and differentiation. Clearly, the extracellular protein SPARC has to be internalised in testis cells in order to rescue testiculogenesis. Furthermore, the assembly of SPARC inside Sertoli, Leydig and germ cells implies its intracellular regulatory role in these cells (Wilson et al., 2006). The testis pathway may down-regulate tissue inhibitors of metalloproteinases (TIMPs) that lead to higher concentrations of SPARC. Cellular export of SPARC is probably absent in the testis, resulting in the internalization of this protein in testis cells. Moreover, the testis pathway may up-regulate receptors for SPARC, such as stabilin-1 that drives endocytosis of this glycoprotein to the interior of the cell followed by its degradation in lysosomes. These processes may ensure proper testis development.

Testis cord formation coincides with the development of testisspecific vascular formation (Brennan et al., 2002; Brennan and Capel, 2004; Coveney et al., 2008). During gonadogenesis blood vessels invade developing ovaries as well as testis. However, in $X Y$ foetuses, the mesonephric vascular plexus located near the gonad-mesonephros border dissolves and releases individual endothelial cells (Fig. 1). These cells migrate into the developing testis and begin to form the wall of the coelomic vessel, a large blood vessel located along the cranio-caudal axis of the male gonad, just under the coelomic epithelium. The inhibition of the development of coelomic vessel branches by impairment in intercellular adhesion of endothelial cells results in the absence of testis cords, which indicates that vasculature is required for the initiation of cord partitioning and also for maintaining the partitions between testis cords (Combes etal., 2009). Pdgfro is significantly up-regulated in the region of future coelomic vessel formation (Jeays-Ward etal., 2004). Moreover, null-mutation in Pdgfro, and likewise in Inhbb (inhibin beta B), results in the disruption of the coelomic vessel (Brennan et al., 2003; Yao et al., 2006). This implies that PDGF and inhibin beta $B$ are required for the origin of this testis-specific vessel. Moreover, vascular endothelial growth factor (VEGF) and kinase domain region receptor (KDR) are involved in testis cord formation as well as in vascular development in rat testis (Bott et al., 2006). Inhibition of angiogenic VEGF isoforms impairs development of sex cords in the testis and follicle progression in the ovary as well as perturbs vasculature formation in both rat testis and ovary. Reduction of anti-angiogenic VEGF isoforms enhances vasculature formation in both testes and ovaries as well as follicle progression, however, disrupts testis cord development (Bott et al., 2008). The mutations affecting vascular development in the testis are combined with the impairment of testis cord formation. This is probably a secondary consequence of vascular disorganization, since developing vessels in the testis may influence cord formation (Brennan and Capel, 2004); similarly, vasculature is required for proper liver and pancreas organogenesis. On the other hand, a couple of sexspecific processes may be regulated by multiple growth factors through a similar signal transduction pathway.

\section{Male-specific migration of mesonephric cells}

The inward migration of mesonephric cells in the gonad is another symptom of testis differentiation (Fig. 2,3; Capel et al., 1999). The latest research has indicated that the great majority of migrating cells are endothelial (Combes et al., 2009), however, previous papers suggested that these cells give rise mainly to endothelial cells but also to interstitial, peritubular and perivascular cells (Buehr etal., 1993; Merchant-Larios etal., 1993; Martineau et al., 1997). This migration, like proliferation of coelomic-derived cells, contributes to the significant growth of the male gonad soon after the sex-determining period. Mesonephric cells are required for proper cord formation and maintenance of Sertoli cell differentiation in a stage-specific manner. The impediment of migration before $11.5 d p c$ results in the disorganization of testis cords and the coelomic vessel. After $12.5 d p c$, migration is not essential for further testis development (Tilmann and Capel, 1999). Surpris-
A

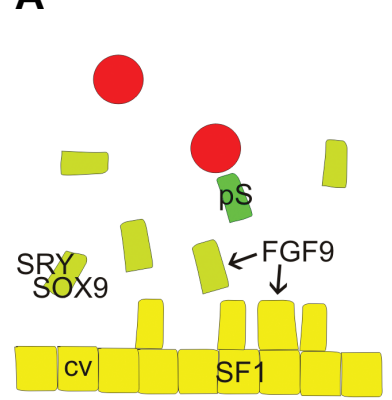

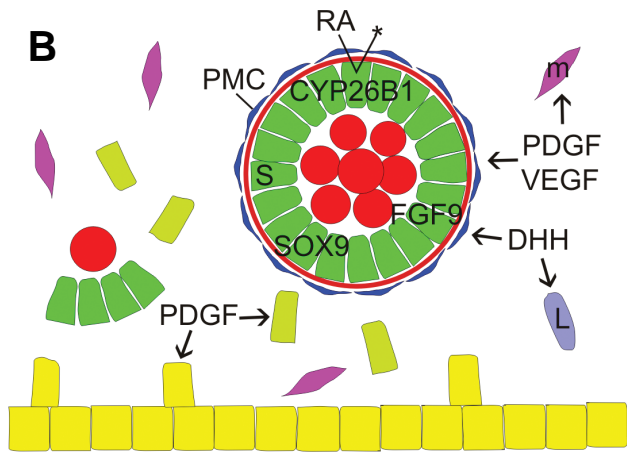

Fig. 3. Molecular and cellular events in developing testis. (A) At 10.5 - 12.5 dpc Sry is expressed in some cells derived from SF1-positive coelomic epithelium (cv). SRY induces Sox9 expression in pre-Sertoli cells (pS) which begin surrounding germ cells (red). SOX9 increases Fgf9 expression. FGF9 enhances proliferation of coelomic epithelium, which results in increase of pre-Sertoli cell number. (B) At $12.5 \mathrm{dpc}$ distinct testis cords are visible. Sertoli cells (S) produce FGF9 which probably regulates their differentiation by nuclear receptors. PDGF mediates following phase of somatic cell proliferation. $\mathrm{DHH}$ with other factors induces fetal Leydig cell (L) as well as peritubular myoid cells (PMC)

differentiation from mesenchymal cells. PMC enclose testis cords and participate in basal membrane formation (red line). PDGF, VEGF and some other factors act as chemoattractants for vascular endothelial cells $(\mathrm{m})$ migrating from mesonephros. These factors are also responsible for testis cord development. Sertoli cells produce CYP26B1 which degrades retinoic acid (RA) and thus prevents meiosis. 
ingly, ectopic mesonephric cell migration induces the testis pathway in the $X X$ gonad, which implies that this process can support sex determination and/or differentiation of the male gonad.

The PDGF pathway is involved in the promotion of mesonephric-cell migration. PDGFR $\alpha$ is located in gonadal cells rather than in mesonephric cells, thus it is a secondary signaling pathway in the control of cell migration (Brennan et al., 2003). Mice lacking PDGFR $\alpha$ are characterized by the disruption of testis vasculature, fewer testis cords and a greatly decreased number of Leydig cells. Interestingly, mice lacking PDGF-A have normal testes with fetal Leydig cells. However, Pdgf-Bexpression in the mouse gonad indicates that PDGF-B may act via PDGFR, promoting mesonephric cell migration and probably in consequence the formation of vasculature and testis cords. The addition of PDGF-B to serum in gonad culture induces testis cord formation, revealing the role of this isoform in testis morphogenesis (Ricci et al., 2004). It appeared that blocked VEGF inhibits endothelial migration in the testis as well as coelomic vessel formation and testis cord development (Cool et al., 2009). It indicates that VEGF may be another key factor in testis development, however, further investigations are needed to clear it. Neurotropin 3 (NT3), another growth factor, is required for proper migration since blocking its action results in the inhibition of migration (Cupp et al., 2000). Suppression of phosphotidylinositol 3-kinase (PI3K), utilized by neurotropin-3, blocks mesonephric cell migration and testis cord formation (Uzumcu et al., 2002). The same study revealed that a mitogen-activated protein (MAP) kinase does not contribute to cell migration but affects testis cord formation. Many factors such as NGFs (nerve growth factors), FGFs, AMH (anti-müllerian hormone), and PDGFs can induce mesonephric cells migration in vitro, but they may not act in vivo. It must be emphasized that PDGF, mediated by PDGF $\alpha$ receptor, has a key role for several processes in testis morphogenesis.

\section{Steroidogenesis as a process specific to the embryonic testis}

The onset of steroidogenesis in the testis is another difference between the developing testis and ovary. Fetal Leydig cells (FLCs) are present in the testis from $12.5 \mathrm{dpc}$ to disappear after birth (Fig. 1,3). It has been suggested that the precursors of these cells may be derived from sites such as coelomic epithelium, mesonephros, adrenal cortex precursor, or even neural crests. Fate-mapping researches suggest that FTCs differentiate from mesenchyme that is derived from both mesonephros and coelomic epithelium. The presumptive fetal Leydig cells reveal expression of $S f 1$, similarly to pre-Sertoli cells. However, in Sertoli cells Sf1 expression decreases during their differentiation, in contrast to Leydig cells in which expression of the gene is maintained (Hatano et al., 1994). Loss-of-function mutation in Pdgfro and Dhh results in the near absence of fetal Leydig cells in mice (Pierucci-Alves et al., 2001, Yao et al., 2002; Brennan et al., 2003). Thus, two signaling molecules, PDGF secreted by Sertoli cells and acting via PDGFR $\alpha$ as well as $\mathrm{DHH}$ secreted by Sertoli cells and acting via the Ptch1 receptor, are required for Leydig cell differentiation. This shows that PDGF is important for testis differentiation not in only a single pathway, but rather performs several distinct tasks in testiculogenesis. Arx, a gene expressed in peritubular, endothelial and fibroblast cells, acts as a paracrine factor influencing the differentiation of Leydig cells (Kitamura et al., 2002). Moreover, mutation in the human ATRX gene causes impaired Leydig cell differentiation (Tang et al., 2004). Nevertheless, the regulation of steroidogenic cell specification in the testis remains unclear and requires further studies.

\section{Ovary}

\section{The onset of meiosis - a symptom of ovary differentiation}

Another difference between a differentiating testis and ovary is the lack of initiation of meiosis in germ cells of the developing $X Y$ gonad. Retinoic acid (RA), diffusing from mesonephroi, induces the expression of Stra8 and causes the onset of meiosis in germ cells of the ovary. Sertoli cells express Cyp26b1 encoding an enzyme (cytochrome P450, family 26, subfamily b, polypeptide 1) that degrades retinoic acid (Fig. 3). Thus, Sertoli cells create a specific environment preventing meiotic division in germ cells, independently of the genetic sex of both Sertoli and germ cells (Bowles et al., 2006; Koubova etal., 2006). This indicates that the commencement of meiosis is not a cell-autonomous process as suggested earlier. Cyp26b1 is expressed in both $\mathrm{XX}$ and $\mathrm{XY}$ undifferentiated gonads and proceeds only in the developing testis (Bowles et al., 2006). This gene is directly up-regulated by SOX9. It explains the lack of CYP26B1 in the developing ovary which enables the onset of meiosis.

Meiotic cells antagonize mesonephric cell migration and testis cord formation (Yao et al., 2003). Thus, it is important that the expression of Cyp26b1 in Sertoli cells occurs before retinoic acid is able to induce meiosis in germ cells. The small cluster of germ cells entering meiosis is discernible in the anterior region of the $X Y$ gonad near the mesonephros. These meiotic germ cells may contribute to the destabilization of testis cords that differentiate into rete testis and efferent ducts (Yao et al., 2003). Degradation of RA may also influence other aspects of gonadogenesis since this process has been shown to disrupt cell migration in rat gonads (Li and Kim, 2004). Null-mutants for Rspo1 display a low level of Cyp26b1, thus a high concentration of RA affects germ cells, resulting in activation of Stra8 (Chassot et al., 2008). Nevertheless, meiosis is impaired in Rspo1 mutants. This does not suggest that there are other ways to induce meiosis besides $\mathrm{RA}$, but rather that the loss of Rspo1 function impairs meiosis.

\section{Robust molecular and dormant structural program of ova- rian development}

If SOX9 and FGF9 do not reach high concentrations in somatic cells, then the genes of the female pathway are up-regulated (Fig. $2 \mathrm{E})$. Beverdam and Koopman (2006) have shown that 242 genes are activated at $11.5 d p c$ in the $\mathrm{XX}$ gonad. Nef and colleagues (2005) revealed that 1223 genes are over-expressed in XX gonads between 10.5 and $13.5 d p c$, implying a switch of the robust genetic program in the differentiating ovary. Ovarian development is considered a dormant process because morphological observations have not revealed significant changes in the embryonic ovary. Only the formation of ovarian follicles and the onset of meiosis are prominent events characteristic for the development of the ovary. The dormant character of ovarian development results from a large amount of repressive molecular interactions taking place in the differentiating ovary. The genetic control of ovary differentiation seems limited to the inhibition of testisspecific cellular events requiring the activation of a large molecu- 
lar machinery. In the $\mathrm{XX}$ gonad, proliferation, mesonephric cell migration, coelomic vessel formation and also testis cord formation are actively repressed by the ovarian pathway.

Some of the first genes up-regulated in XX gonads are Cdkn1a (p21), Cdkn1b (p2) and Cdkn1c (p5) that encode inhibitors of cyclin-dependent kinases (Nef et al., 2005). These proteins can up-regulate Wnt4 expression and in consequence the ovarian pathway, moreover, they can repress cell division, which may result in the lack of significant cell proliferation in the ovary. Proliferation does not suffice for a switch in the testis pathway because it is not up-regulated in the XX gonad exposed to ectopic mitogenes. This suggests that the inhibition of proliferation is not essential for female sex determination, whereas proliferation is blocked in the $\mathrm{XX}$ gonad since this process is superfluous for ovarian development.

Null-mutation in Wnt4 causes mesonephric cell migration into the $X X$ gonad, which implies that a high concentration of the WNT4 pathway directly or indirectly blocks testis-specific migration in the differentiating ovary (Jeays-Ward et al., 2003). This is important for female sex determination since ectopic mesonephric cell migration into the $X X$ gonad results in the upregulation of the testis pathway (Tilmann and Capel, 1999). Thus, mesonephric-derived cells in the gonad may produce factors positively influencing the testis pathway or their streams may force testis cord formation, which may influence the genes of the male pathway. Moreover, in the same mutants lacking WNT4, endothelial cells begin to form the coelomic vessel in the $X X$ gonad. Similarly, testis-specific vasculature also develops in the gonads of females lacking follistatin downstream of WNT4 (Yao et al., 2004). WNT4, one of the main ovarian-determining factors, together with follistatin represses the expression of inhibin $B$ $($ Inhbb) which results in the absence of the formation of the testis vasculature (Yao et al., 2006). Moreover, in XY Wnt4t- the PDGFR $\alpha$-positive region of the gonad is extended (Jeays-Ward et al., 2004). This indicates that WNT4 can repress coelomic vessel formation by inhibition of the PDGF pathway. Nevertheless, the over-expression of Wnt4 in the XY gonad is insufficient to prevent coelomic vessel formation in the differentiating testis (Jeays-Ward et al., 2003). In the XY testis WNT4 can repress the formation of the coelomic vessel and needs to be down-regulated since vasculature begins to develop earlier in the $X Y W_{n t 4^{--}}$testis than in XY Wnt4+-- (Jeays-Ward et al., 2004). WNT4 also antagonizes the migration of steroidogenic cell precursors to the $\mathrm{XX}$ gonads, thus this cell population is observed in $\mathrm{XX} \mathrm{Wnt}^{/-}$

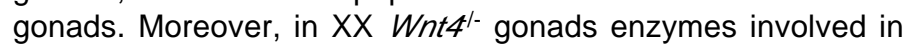
steroidogenesis, e.g. 3- $\beta$ HSD and CYP17, are up-regulated, and such gonads produce testosterone, which is probably the main source of masculinization of $W_{n t 4^{--}} \mathrm{XX}$ individuals. The population of ectopic steroidogenic cells in $W n t 4^{/-} \mathrm{XX}$ gonads are adrenal precursors rather than Leydig cells and are also observed in Wnt4/- XY gonads (Vainio et al., 1999; Heikkila et al., 2005). This shows that WNT4 is engaged in the proper separation of adrenal cells from the gonadal primordium and probably does not repress steroidogenesis and/or Leydig cell differentiation in $\mathrm{XX}$ gonads (Jeays-Ward et al., 2003; Yao, 2005).

\section{Contribution of germ cells and steroid hormones to gonadal differentiation}

The female germ cells are surrounded by follicular cells that do not express Cyp26b1. Thus, retinoic acid released from the mesonephros reaches female germ cells and induces Stra8 expression, inducing meiosis at 13.5 dpc (Bowles et al., 2006; Koubova et al., 2006). Meiotic germ cells interfere with testis cords and mesonephric cell migration in co-cultures with differentiating testes, which acts via short-range signalling and/or cell-cell interactions between somatic and germ cells. However, premeiotic germ cells do not have this ability (Yao et al., 2003), indicating that the initiation of meiosis marks the end of susceptibility of the XX gonad to sex reversal. Thus the meiotic germ cells contribute to the canalisation of the ovarian pathway. The presence of meiotic germ cells is essential for ovary differentiation, despite the uncertainty of the molecular contribution of germ cells to ovarian differentiation. A lack of germ cells in the early ovary, resulting from mutations of some genes such as Wnt4, Fst, Fig/ $\alpha$ or from the influence of substances such as $\mathrm{AMH}$ or busulfan, causes rapid degeneration of follicles or even impedes their formation. In such ovaries symptoms of secondary sex reversal are discernible (Vainio et al., 1999; Soyal et al., 2000; Yao et al., 2004). Somatic cells trans-differentiate into Sertoli cells that gather to form testis cord-like structures. Differentiation of Leydig cells has also been observed in such secondary sex reversed gonads. Even Sertoli cell markers begin to be expressed in Wnt4 1- XX gonads. Similar consequences follow mutation of genes encoding estrogen receptors $(E R \alpha, E R \beta)$ and aromatase (Couse etal., 1999; Dupont etal., 2003). It can be assumed that both germ cells and estrogen signalling are required for the maintenance of ovarian structure in the postnatal period, however, they are not essential for sex determination nor ovary differentiation during the embryonic period.

\section{Conclusions}

There are several signs in gonadal differentiation through which gonadal sex can be established. FGF9 acting via the FGFR2 receptor located in the cell membrane probably drives the proliferation of somatic cells in differentiating testis, while FGFR2 in nuclei mediates Sertoli cell differentiation. Mesonephric cell migration is another symptom of testis differentiation and is controlled by PDGF acting via PDGFR $\alpha$. Mesonephric cells contribute to testis cord development, coelomic vessel formation and steroidogenesis. PDGF also mediates cell proliferation in the developing testis after the sex-determining period and coelomic blood vessel formation. The signalling proteins FGF9 and PDGF partake in establishing testis structure and thus in testis differentiation. Differentiation of steroidogenic cells in the developing testis is controlled by DHH and PDGF. The absence of meiosis in the developing testis is a consequence of the enclosure of germ cells by Sertoli cells. Cyp26b1, an enzyme present in Sertoli cells, inhibits retinoic acid which acts as a meiosis inductor. Further analyses are needed to explain the role of VEGF in testis development as well as to test an influence of VEGF absence on oogenesis and thus ovary development. Proliferation, coelomic blood vessel formation and testis cord formation are associated and impairment in one of these processes always results in the disruption of testis development. Proliferation supplies cells for testis cord formation while mesonephros-derived cells contribute to the development of testis cords since endothelial cells immigrating from mesonephroi form blood vessels directing the distri- 
bution of testis cords. The interactions between cellular processes such as proliferation, migration and cell differentiation are becoming clearer but their molecular background remains unexplained. Mouse embryos carrying mutations in genes responsible for gonadal development have pleiotropic defects in the gonad, indicating that one factor may have distinct roles in gonadogenesis through several pathways. Moreover, processes contributing to gonadal development are co-dependant and the disruption of one can completely disturb gonadal formation. Relatively little is known of the genes participating in gonadal differentiation. This process seems much more complicated than has been hitherto thought. The molecular basis of induction of Leydig cell differentiation has been solved but the source of fetal and adult Leydig cells is still unknown. Moreover, germ cell localisation is important for gonadal differentiation and that is why the influence of sex determining and sex differentiating genes on intercellular connections and extracellular matrix components are in need of explanation. The actions of several growth factors in vitro have been described, nevertheless, their role in gonadogenesis in vivo remains to be shown.

\section{References}

ADAMS, I.R. and MCLAREN, A. (2002). Sexually dimorphic development of mouse primordial germ cells: switching from oogenesis to spermatogenesis. Development 129: 1155-1164.

BEVERDAM, A. and KOOPMAN, P. (2006). Expression profiling of purified mouse gonadal somatic cells during the critical time window of sex determination reveals novel candidate genes for human sexual dysgenesis syndromes. Hum Mol Genet 15: 417-431.

BOTT, R.C., MCFEE, R.M., CLOPTON, D.T., TOOMBS, C. and CUPP, A.S. (2006). Vascular endothelial growth factor and kinase domain region receptor are involved in both seminiferous cord formation and vascular development during testis morphogenesis in the rat. Biol Reprod 75: 56-67.

BOTT, R.C., CLOPTON, D.T. and CUPP, AS. (2008). A proposal role for VEGF isoforms in sex-specific vasculature development in the gonad. Reprod Domest Anim 43: 310-316.

BOWLES, J., KNIGHT, D., SMITH, C., WILHELM, C., RICHMAN, J., MAMIYA, S., YASHIRO, K., CHAWENGSAKSOPHAK, K., WILSON, M.J., ROSSANT, J., HAMADA, H. and KOOPMAN, P. (2006). Retinoid signaling determines germ cell fate in mice. Science 312: 596-600.

BREKKEN, R.A. and SAGE, E.H. (2001). SPARC, a matricellular protein, at the crossroads of cell-matrix communication. Matrix Bio/19: 816-827.

BRENNAN, J., KARL, J. and CAPEL, B. (2002). Divergent vascular mechanisms downstream of Sryestablish the arterial system in the XY gonad. Dev Bio/244: 418-428.

BRENNAN, J., TILMANN, C. and CAPEL, B. (2003). Pdgfr- $\alpha$ mediates testis cord organization and fetal Leydig cell development in the XY gonad. Genes Dev17: 800-810.

BRENNAN, J. and CAPEL, B. (2004). One tissue, two fates, molecular genetic events that underlie testis versus ovary development. Nat Rev Genet 5: 509521.

BUEHR, M., GU, S. and MCLAREN, A. (1993). Mesonephric contribution to testis differentiation in the fetal mouse. Development 117: 273-281.

CAPEL, B., ALBRECHT, K.H., WASHBURN, L.L. and EICHER, E.M. (1999). Migration of mesonephric cells into the mammalian gonad depends on Sry. Mech Dev 84: 127-131.

CHASSOT, A.A., RANC, F., GREGOIRE, E.P., ROEPERS-GAJADIEN, H.L., TAKETO, M.M., CAMERINO, G., DE ROOIJ, D.G., SCHEDL, A. and CHABOISSIER, M.C. (2008). Activation of $\beta$-catenin signaling by Rspo1 controls differentiation of the mammalian ovary. Hum Mol Genet 17: 1264-1277.

COMBES, A.N., WILHELM, D., DAVIDSON, T., DEJANA, E., HARLEY, V., SINCLAIR, A. and KOOPMAN, P. (2009). Endothelial cell migration directs testis cord formation. Dev Bio/326: 112-120.

COOL, J., CARMONA, F.D., SZUCSIK, J.C. and CAPEL, B. (2008). Peritubular myoid cells are not the migrating population required for testis cord formation in the XY gonad. Sex Dev2: 128-133.

COOL, J., COVENEY, D., CAPEL, B. (2009). Testis morphogenesis requires VEGF mediated endothelial migration via a novel mechanism of vascular remodeling. Fifth International Symposium on Vertebrate Sex Determination, Kona, Hawaii.

COVENEY, D., COOL, J., OLIVIER, T. and CAPEL, B. (2008). Four-dimensional analysis of vascularization during primary development of an organ, the gonad. Proc Natl Acad Sci USA 105: 7212-7217

COUSE, J.F., HEWITT, S.C., BUNCH, D.O., SAR, M., WALKER, V.R., DAVIS, B.J. and KORACH, K.S. (1999). Postnatal sex reversal of the ovaries in mice lacking estrogen receptors alpha and beta. Science 286: 2328-2331.

CUPP, A.S., KIM, G.H. and SKINNER, M.K. (2000). Expression and action of neurotropin-3 and nerve growth factor in embryonic and early postnatal rat testis development. Biol Reprod63: 1617-1628.

DUPONT, S., DENNEFELD, C., KRUST, A., CHAMBON, P. and MARK, M. (2003). Expression of Sox9 in granulosa cells lacking the estrogen receptors, ERalpha and ERbeta. Dev Dyn 226: 103-106.

FROJDMAN, K., PARANKO, J., VIRTANEN, I. and PELLINIEMI, L.J. (1992). Intermediate filaments and epithelial differentiation of male rat embryonic gonad. Differentiation 50: 113-123.

HEIKKILA, M., PRUNSKAITE, R., NAILLAT, F., ITARANTA, P., VUORISTO, J., LEPPALUOTO, J., PELTOKETO, H. and VAINIO, S. (2005). The partial female to male sex reversal in Wnt4-dificient females involves induced expression of testosterone biosynthetic genes and testosterone production, and depends on androgen action. Endocrinology 146: 4016-4023.

GRIMMOND, S., HATEREN, N.V., SIGGERS, P., ARCELL, R., LARDEL, R. SOARCES, M.B., DE FATIMA BONALDO, M., SMITH, L., TYMOWSKALALANNE, Z., WELLS, C. and GREENFIELD, A. (2000). Sexually dimorphic expression of protease nexin-1 and vanin-1 in the developing mouse gonad prior to overt differentiation suggests a role in mammalian sexual development. Hum Mol Genet 9: 1553-1560.

HATANO, O., TAKAYAMA, K., IMAL, T., WATERMAN, M.R., TAKAKUSU, A. OMURA, T. and MOROHASHI, K. (1994). Sex-dependent expression of a transcription factor, Ad4BP, regulating steroidogenic $\mathrm{P}-450$ genes in the gonads during prenatal and postnatal rat development. Development 120: 27872797.

JEAYS-WARD, K., DANDONNEAU, M. and SWAIN, A. (2004). Wnt4 is required for proper male as well as female sexual development. Dev Bio/276: 431-440.

JEAYS-WARD, K., HOYLE, C., BRENNAN, J., DANDONNEAU, M., ALLDUS, G., CAPEL, B. and SWAIN, A. (2003). Endothelial and steroidogenic cell migration are regulated by WNT4 in the developing mammalian gonad. Development 130 : 3663-3670.

KARL, J. and CAPEL, B. (1998). Sertoli cells of the mouse testis originate from the coelomic epithelium. Dev Bio/203: 323-333.

KIM, Y., BINGHAM, N., SEKIDO, R., PARKER, K.L., LOVELL-BADGE, R. and CAPEL, B. (2007). Fibroblast growth factor receptor 2 regulates proliferation and Sertoli differentiation during male sex determination. Proc Nat/ Acad Sci USA 104: 16558-16563.

KIM, Y., KOBAYASHI, A., SEKIDO, R., DINAPOLI, L., BRENNAN, J., CHABOISSIER, M.C., POULAT, F., BEHRINGER, R.R., LOVELL-BADGE, R. and CAPEL, B. (2006). Fgfg and Wnt4 act as antagonistic signals to regulate mammalian sex determination. PLOS Bio/4: e187.

KITAMURA, K., YANAZAWA, M., SUGIYAMAA, N., MIURA, H., IIZUKA-KOGO, A., KUSAKA, M., OMICHI, K., SUZUKI, R., KATO-FUKUI, Y., KAMIIRISA, K., MATSOU, M., KAMIJO, S., KASAHARA, M., YOSHIOKA, H., OGATA, T., FUKUDA, T., KONDO, I., KATO, M., DOBYNS, W.B., YOKOYAMA, M. and MOROHASHI, K. (2002). Mutation of $A R X$ causes abnormal development of forebrain and testes in mice and $X$-linked lissencephaly with abnormal genitalia in humans. Nat Genet 32: 359-369.

KOUBOVA, J., MENKE, D.B., ZHOU, Q., CAPEL, B., GRISWOLD, M.D. and PAGE D.C. (2006). Retinoic acid regulates sex-specific timing of meiotic initiation in mice. Proc Natl Acad Sci USA 103: 2474-2479.

$\mathrm{LI}, \mathrm{H}$. and KIM, K.H. (2004). Retinoic acid inhibits rat XY gonad development by blocking mesonephric cell migration and decreasing the number of gonocytes. 
Biol Reprod 70: 687-693.

MARTINEAU, J., NORDQVIST, K., TILMANN, C., LOVELL-BADGE, R. and CAPEL, B. (1997). Male-specific cell migration into the developing gonad. Curr Bio/7: 958-968.

MERCHANT-LARIOS, H., MORENO-MENDOZA, N. and BUEHR, M. (1993). The role of the mesonephros in cell differentiation and morphogenesis of the mouse fetal testis. Int J Dev Bio/37: 407-415.

MITTWOCH, U. (2000). Genetics of sex determination, exceptions that prove the rule. Mol Genet Metab 71: 405-410.

NEF, S., SCHAAD, O., STALLINGS, N.R., CEDERROTH, C.R., PITETTI, J.L., SCHERER, G., MALKI, S., DUBOIS-DAUPHIN, M., BOIZET-BONHOURE, B., DESCOMBES, P., PARKER, K.L. and VASSALLI, J.D. (2005). Gene expression during sex determination reveals a robust female genetic program at the onset of ovarian development. Dev Bio/287: 361-377.

PIERUCCI-ALVES, F., CLARK, A.M. and RUSSELL, L.D. (2001). A developmental study of the Desert hedgehog-null mouse testis. Biol Reprod 65: 1392-1402.

PITARI, G., MALERGUE, F., MATIN, F., PHILIPPE, J., MASSUCCI, M., CHABRET, C., MARAS, B., DUPRE, S., NAQUET, P. and GALLAND, F. (2000). The transcription factor SF-1 and SOX9 regulate expression of Vanin-1 during mouse testis development. FEBS Lett 483: 149-154.

RICCI, G., CATIZONE, A. and GALDIERI, M. (2004). Embryonic mouse testis development: role of platelet derived growth factor (PDGF-BB). J Cel/ Physio/ 200: 458-467.

SCHMAHL, J. and CAPEL, B. (2003). Cell proliferation is necessary for the determination of male fate in the gonad. Dev Bio/258: 264-276.

SCHMAHL, J., EICHER, E.M., WASHBURN, L.L. and CAPEL, B. (2000). Sry induces cell proliferation in the mouse gonad. Development 127: 5-73.

SCHMAHL, J., KIM, Y., COLVIN, J.S., ORNITZ, D.M. and CAPEL, B. (2004). Fgf9 induces proliferation and nuclear localization of FGFR2 in Sertoli precursors during male sex determination. Development 131: 3627-3636.

SOYAL, S.M., AMLEH, A. and DEAN, J. (2000). FIGalpha, a germ cell-specific transcription factor required for ovarian follicle formation. Development 127: 4645-4654

SWAIN, A. and LOVELL-BAGDE, R. (1999). Mammalian sex determination, A molecular drama. Genes Dev 13: 755-767.

TANG, P., PARK, D.J., MARSHALL GRAVES, J.A. and HARLEY, V.R. (2004). ATRX and sex differentiation. Trends Endocrinol Metab 15: 339-344.

TEVOSIAN, S.G., PU, W. and MANUYLOV, N.L. (2009). An unexpected role for GATA4 in embryonic gonadal development. $5^{\text {h }}$ International Symposium on Vertebrate Sex Determination, pp. 18 (Abstr.)

TILMANN, C. and CAPEL, B. (1999). Mesonephric cell migration induces testis cord formation and Sertoli cell differentiation in the mammalian gonad. Development
126: $2883-2890$

TÖHÖNEN, V., FRYGELIUS, J., MOHAMMADIEH, M., KVIST, U., PELLINIEMI, L.J., O'BRIEN, K., NORDQVIST, K. and WEDELL, A. (2005). Normal sexual development and fertility in testatinknockout mice. Mol Cel/ Bio/25: 4892-4902.

UZUMKU, M., WESTFALL, S.D., DIRKS, K.A. and SKINNER, M.K. (2002). Embryonic testis cord formation and mesonephric cell migration requires the phosphotidylinositol 3-kinase signaling pathway. Biol Reprod 67: 1927-1935.

VAINIO, S., HEIKKILA, M., KISPERT, A., CHIN, N. and MCMAHON, A.P. (1999) Female development in mammals is regulated by Wnt-4 signalling. Nature 397 : 405-409.

VIRTANEN, I., KALLAJOKI, M., NARVANEN, O., PARANKO, J., THOTENELL, L.E., MIETTINEN, M. and LEHTO, V.P. (1986). Peritubular myoid cells of human and rat testis are smooth muscle cells that contain desmin-type intermediate filaments. Anat Rec 215: 10-20.

WILSON, M.J., BOWLES, J. and KOOPMAN, P. (2006). The matricellular protein SPARC is internalized in Sertoli, Leydig, and germ cells during testis differentiation. Mol Reprod Dev73: 531-539.

WILSON, M.J., JEYASURIA, P., PARKER, K.L. and KOOPMAN, P. (2005). The transcription factors steroidogenic factor-1 and SOX9 regulate expression of Vanin-1 during mouse testis development. J Biol Chem 280: 5917-5923.

WITSCHI, E. (Ed.) (1956). Development of Vertebrates. WB Saunders, Philadelphia.

YAN, Q. and SAGE, E.H. (1999). SPARC, a matricellular glycoprotein with important biological functions. J Histochem Cytochem 47: 1495-1506.

YAO, H.H. (2005). The pathway to femaleness, current knowledge on embryonic development of the ovary. Mol Cell Endocrino/230: 87-93.

YAO, H.H., AAREMA, J. and HOLTHUSEN, K. (2006). Sexually dimorphic regulation of inhibin beta $\mathrm{B}$ in establishing gonadal vasculature in mice. Biol Reprod 74: 978-983

YAO, H.H. and CAPEL, B. (2002). Disruption of testis cords by cyclopamine or forskolin reveals independent cellular pathways in testis organogenesis. Dev Bio/246: 356-365.

YAO, H.H., DINAPOLI, L. and CAPEL, B. (2003). Meiotic germ cells antagonize mesonephric cell migration and testis cord formation in mouse gonads. Deve/ opment 130: 5895-5902.

YAO, H.H., MATZUK, M.M., JORGEZ, C.J., MENKE, D.B., PAGE, D.C., SWAIN, A. and CAPEL, B. (2004). Follistatin operates downstream of Wnt4 in mammalian ovary organogenesis. Dev Dyn 230: 210-215.

YAO, H.H., WHORISKEY, W. and CAPEL, B. (2002). Desert Hedgehog/Patched 1 signaling specifies fetal Leydig cell fate in testis organogenesis. Genes Dev16: 1433-1440. 


\section{Further Related Reading, published previously in the Int. J. Dev. Biol.}

See Special Issue Pattern Formation edited by Michael K. Richardson and Cheng-Ming Chuong at:

http://www.ijdb.ehu.es/web/contents.php?vol=53\&issue=5-6

In vitro germ cell differentiation during sex differentiation in a teleost fish

Tohru Kobayashi

Int. J. Dev. Biol. (2010) 54: 105-111 (doi: 10.1387/ijdb.082836tk)

Dicer is required for Sertoli cell function and survival

Gwang-Jin Kim, Ina Georg, Harry Scherthan, Matthias Merkenschlager, Florian Guillou, Gerd Scherer and Francisco Barrionuevo

Int. J. Dev. Biol. (2010) 54: 867-875 (doi: 10.1387/ijdb.092874gk)

Gonadal defects in Cited2 -mutant mice indicate a role for SF1 in both testis and ovary differentiation

Alexander N. Combes, Cassy M. Spiller, Vincent R. Harley, Andrew H. Sinclair, Sally L. Dunwoodie, Dagmar Wilhelm and Peter Koopman Int. J. Dev. Biol. (2010) 54: 683-689 (doi: 10.1387/ijdb.092920ac)

The spatio-temporal pattern of testis organogenesis in mammals - insights from the mole Francisco D. Carmona, Darío G. Lupiáñez, José-Ezequiel Martín, Miguel Burgos, Rafael Jiménez and Federico Zurita Int. J. Dev. Biol. (2009) 53: 1035-1044

Foetal germ cells: striking the balance between pluripotency and differentiation Patrick Western

Int. J. Dev. Biol. (2009) 53: 393-409

Aard is specifically up-regulated in Sertoli cells during mouse testis differentiation Terje Svingen, Annemiek Beverdam, Pali Verma, Dagmar Wilhelm and Peter Koopman Int. J. Dev. Biol. (2007) 51: 255-258

The formation of primordial germ cells from germline cells in spherical embryos derived from the blastodisc of 2-cell embryos in goldfish, Carassius auratus

Satoshi Otani, Tomoe Kitauchi, Taiju Saito, Suzu Sakao, Shingo Maegawa, Kunio Inoue, Katsutoshi Arai and Etsuro Yamaha

Int. J. Dev. Biol. (2005) 49: 843-850

Effects of FGF9 on embryonic Sertoli cell proliferation and testicular cord formation in the mouse

Louise Willerton, Robert A. Smith, David Russell and Sarah Mackay

Int. J. Dev. Biol. (2004) 48: 637-643

Sex reversal of genetic females $(\mathrm{XX})$ induced by the transplantation of $\mathrm{XY}$ somatic cells in the medaka, Oryzias latipes

Al Shinomiya, Naoki Shibata, Mitsuru Sakaizumi and Satoshi Hamaguchi

Int. J. Dev. Biol. (2002) 46: 711-717

Charting the course of ovarian development in vertebrates

Kelly A Loffler and Peter Koopman

Int. J. Dev. Biol. (2002) 46: 503-510

Germ cells, gonads and sex reversal in marsupials

M B Renfree and G Shaw

Int. J. Dev. Biol. (2001) 45: 557-567

The allocation and differentiation of mouse primordial germ cells

T E Tsang, P L Khoo, R V Jamieson, S X Zhou, S L Ang, R Behringer and P P Tam Int. J. Dev. Biol. (2001) 45: 549-555

Differentiation of mouse primordial germ cells into female or male germ cells N Nakatsuji and S Chuma Int. J. Dev. Biol. (2001) 45: 541-548

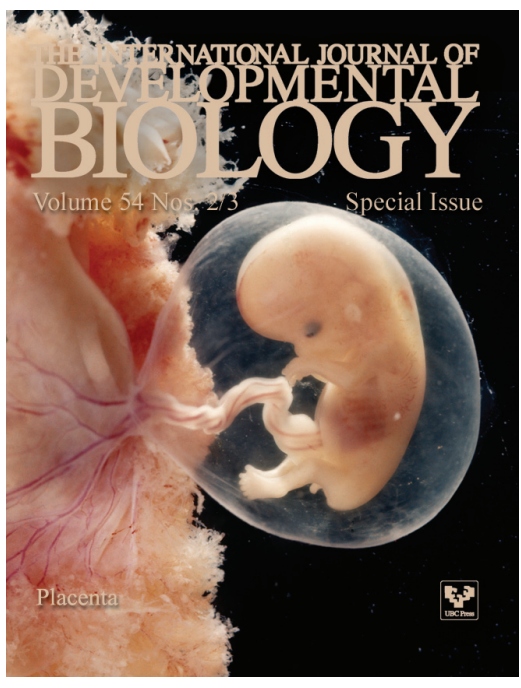

5 yr ISI Impact Factor $(2008)=3.271$

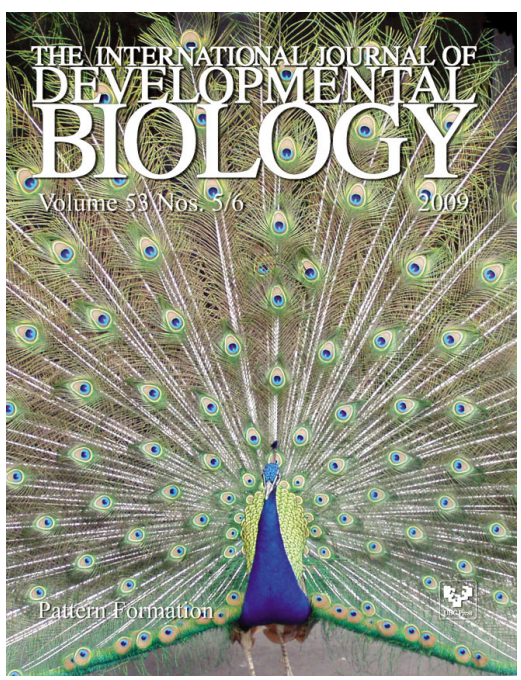

